\section{1. 明治維新前の大分累の体育史}

$$
\text { 大分大学 平 稳 }
$$

I. 序

近世に打ける藩校は，単なる支配階股である武士の教 育機閣ではなく，清校を中心に地方文化の発展と庶民の 生活向上にす多くの頁献をしている，そこで苚校におけ る武士教育の内容行いてみると，知的な学科とあわせ て，一方，武術の隹練に上る技能と体力の表成に励んで おり，武士道の性格つけに努力しているのが同われる.

これらについて分析的研究を行ない，一地方の特殊棵 境偪かれている各藩について，中央との関連性や，そ の比校桧討を試みる。

\section{II. 考暴内容}

（1）豊前・豊後各落の細分化について，(2）藩校の発 達段階について，(3) 落枚の教育内容について，(4) 武 道教育とその内容について，(5) 武道施設について，

(6) 私望について。

\section{III. 结果の考実}

（1）婁前・曹後は8 小藩が分立しており，その中に 5 他落領と幕府領が介在しており，特殊な環境であった。
（2）藩校の創立は，全国的にみて，岡葓・府内落・佐伯 藩が早、，他の蔳す殆んどが天保年代汇創立が終ってい

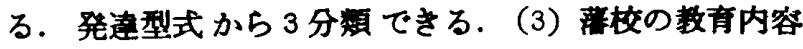
は，全般的に学科目が整䚚されており，文学について は，外棣清が皇学・国学に盛んである，武術について

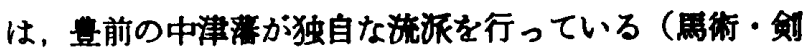

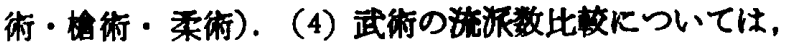
全国比率か一一段江低い，特飞，兵学・弓術次いで馬術・ 砲術・柔術が著しく目立つ.（5）武道施設についてみる と，文学と同棣に中央との関連が強くみられる。しか

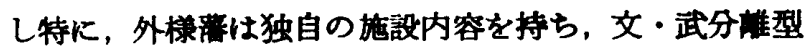

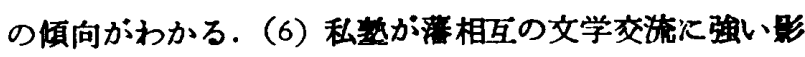
需を与えているのが認められる。武術においても，その 影䇾があるものと推察される。

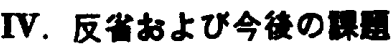

（1）武術に開与る资料が散逸しておるため，調查研究 の困雉性を痛感した（2）さらに，武術の内容について 調査研究を深める必要性を瑟め, 明治䊒新前後における 潘校の影票について，比校検討を行なら。

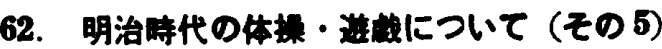

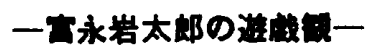

知数育大学 川岛 虎 雄

菑永岩太郎は日店 2 年 (1866) 1月14日に肥前国彼 杵郡三浦村に生まれた。明治 30 年 (1897) 1月 21 日， 彼が31才の時に高等師䈱学校訓導を科命し，明治 37 年 （1904）2月13日，依願免本官となるまで，満 7 年の

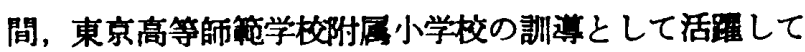
いる. 彼か门教育的遊戱の原理及実際」を刊行したの は、明治 34 年 (1901) 7 月 1 日であり，この著畫は東 京都神田泰神保町 2 番地, 同文館より発行された 288 頁 にわたる名著である、この著は上䌙原理の部と下編実际 の部よりなり，原理の部は，總論，遊戱の好果，児童の

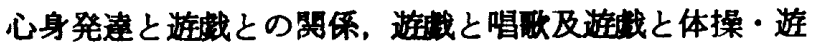
觑に関する歴史，遊戱の稙類，教授法の 7 節からなつて

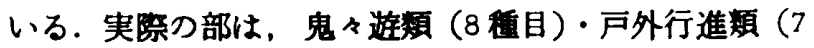
種目) - 唱歌遊類 (9租目) - 用器競争類 (21 種目) - 徒 手競争類 (16 稙目) - 智的競争類 (12 種目) - 戦争遊類 （16種目）に分類している.

彼の遊䖗観とみなされるものは総論の「遊戱と訓練」
の項にみられる、すなわち，「道锶教育，すなわち，品 性に対する一事なり，夫れ界童は学校に入り，多くの児 童に交ると同時に，公共心を奐起せらるるすのなり。こ の公共心快実に人生必須の基本にして，児苜はこれによ りて，後日家稓的生活・社会的生活，なお進みては，国 家似生活を立つるの基攵をなするのなり……とある. 彼は道徳的品性陶治のみでなく，道徳的生活が大切であ ることを強調している．国家主美の立場を強調し，俔人 を国民的に発逵せしめんとする立場をとっている．これ は彼が來岡常荿の「小学教授法」や俑口旖次郎の「柣合 主義新教授法」の影得をらけているように思われる。

強健な身体の市成という明治時代の体育得に制しつ つ，明治 23 年（1890）の 教青搉語奐発以来の我が国の 忠孝思想にもとつく倫理観があらわれている，徒来の普 通体操では满たされない心身雨面の効果を遊线に期待し て，遊戱が贵重であることを強調し，遊戱の指道に上っ て，健全な心身の育成をねらっている点は同じだが，日 路の大戦をひかえての当時と，個人の完成を目さす教育 理念の現在とでは，相当のずれがあるのも当然なことで ある・ 